\title{
EXPERIMENTAL INVESTIGATION OF WEAR BEHAVIOUR
}

\section{OF A356-TiB 2 METAL MATRIX COMPOSITES}

\author{
G. SAI KRISHNAN ${ }^{1}$, L. GANESH BABU ${ }^{2} \&$ N. SIVA SHANMUGAM ${ }^{3}$ \\ ${ }^{1}$ Assistant Professor Rajalakshmi Institute of Technology, Chennai, Tamil Nadu, India \\ ${ }^{2}$ Assistant-Professor, Head of Mechatronics Engineering, Tishk International University, Iraq \\ ${ }^{3}$ Assistant Professor Rajalakshmi Institute of Technology, Chennai, Tamil Nadu, India
}

\section{ABSTRACT}

Aluminium-Silicon (Al-Si) alloys have attractive physical and mechanical properties. They are light weight (app. 3x lighter than gray cast iron and steel), low cost of production (with sand casting technology), easy to machine and have satisfactory mechanical properties with good recycling possibilities (up to $95 \%$ ). Nevertheless, one of the major drawbacks of these alloys is their low wear resistance. In order to improve its wear characteristic many Particle reinforced Aluminium Matrix Composites (PAMCs) were developed using $\mathrm{SiC}, \mathrm{TiC}, \mathrm{B}_{4} \mathrm{C}, \mathrm{TiB}, \mathrm{Gr}, \mathrm{MoS}{ }_{2}$, and fly ash as reinforcement particles by different methods (Stir casting, Compo casting, Powder Metallurgy, in-situ method using salts and spray deposition) and their wear characteristics were also studied But there is no research work done on wear characteristics of semisolid processed PAMCs. So a MMC of aluminium A356 reinforced with 5\%TiB ${ }_{2}$ was developed by semi solid process and its dry sliding wear characteristic were studied using pin on disc machine with disc material of EN31 steel (55-60 HRC) under the condition at sliding velocity varies from $1 \mathrm{~m} / \mathrm{s}$ to $3 \mathrm{~m} / \mathrm{s}$ and applied load varies from $10 \mathrm{~N}$ to $30 \mathrm{~N}$ at constant sliding distance $3000 \mathrm{~m}$. A comparative study was done between A356 alloy, A356-5\% TiB ${ }_{2}$ in-situ composite and Semisolid processed alloy, composite it was found that semisolid processed alloy and composite shows more wear than commercial alloy and in-situ composite.

KEYWORDS: In-Situ MMCs Al, Thixo Forming, Dry Sliding Wear \& Taguchi Techniques

Received: Apr 03, 2019; Accepted: Apr 23, 2019; Published: Jun 03, 2019; Paper Id.: IJMPERDJUN2019141

\section{INTRODUCTION}

MMCs offer the following advantages: Major weight savings due to higher strength-to-weight ratio Exceptional dimensional stability, higher elevated temperature stability, i.e., creep resistance significantly improved cyclic fatigue characteristics. With respect to PMCs, MMCs offer these distinct advantages like Higher strength and stiffness, Higher service temperatures, Higher electrical conductivity, Higher thermal conductivity, Better transverse properties Improved joining characteristics, Radiation survivability, Little or no contamination. Wear is the most commonly encountered industrial problems leading to the replacement of componentsand assemblies in engineering. [1]

Wear is due to following mechanism as Abrasive, Adhesive, Erosion, Fretting and Chemical in industries wear is mainly due to abrasive upto $55 \%$ and Adhesive upto $15 \%$ [2]. Aluminium alloys are widely used for commercial application in the transportation, construction and similarly Engineering industries. Nowadays, main focus is given to aluminium as matrix material because of its unique combination of good corrosion resistance, low electrical resistance and it possesses excellent mechanical properties in addition to good corrosion resistance due to 
which the alloy finds extensive application in Naval vessels manufacturing [3]. The wear resistance of aluminium alloys can be further improved by means of addition of reinforcement either by ex-situ or in-situ [4]. Both the hypoeutectic and hypereutectic Al-Si alloys have been in use for the tribological components of internal combustion engines in dry and lubricated contacts for long time. Wear rate decrease and load carrying capacity increase with increasing silicon content [5].The wear rate of hypoeutectic Al-Si alloy is less than the wear rate of hypereutectic alloy[5][6].

Wear rate of $\mathrm{A} 356-\mathrm{SiC}_{\mathrm{p}}$ decreases with increase in $\mathrm{SiC}_{\mathrm{p}}$ on Pin on Disc experiment at load 192N, sliding speed 1 to $5 \mathrm{~m} / \mathrm{s}$ and sliding distance $15 \mathrm{Km}$ [7]. The eutectic alloys shows the lower wear rate compared with all the alloys in Al-Si alloy system and the wear is mild when applied load is less than $35 \mathrm{~N}$ and sliding speed $5.8 \mathrm{~m} / \mathrm{s}$ in Pin on Disc experiment [8]. Delaminative wear, abrasive wear and oxidative wear was observed in Al-7Si alloy [9]. The behaviour of aluminium reinforced with $\mathrm{TiC}, \mathrm{TiB}_{2}, \mathrm{~B}_{4} \mathrm{C}, \mathrm{SiC}$ were synthesized and found that $\mathrm{TiB}_{2}$ showed better mechanical property than other reinforcement [10].Mechanical properties of A356 are improved by compo casting than in stir casting [11]. The in-situ techniques to fabricate aluminium based composite has improved the adhesion at interface and its mechanical properties [12]. The presence of $\mathrm{TiB}_{2}$ greater than $2.5 \%$ in $\mathrm{T} 6$ treated $\mathrm{A} 356$ increase coefficient of friction at sliding speed $1 \mathrm{~m} / \mathrm{s}$ and 1800m of sliding distance for varying loads(19.6-78.4 N) in Pin on Disc experiment not varying the sliding velocity [13]. Deuis et.al reviewed the wear behaviour of Al-Si alloys and other Al-based composite and suggested the effect of in-situ $\mathrm{TiB}_{2}$, TiC and $\mathrm{SiO}_{2}$ particles towards the wear behaviour needs further investigation [4].Thixoformable alloys should have solidification interval range between $50-100^{\circ} \mathrm{C}$, Temperature sensitivity at 0.4 fraction liquid is around $0.03 /{ }^{\circ} \mathrm{C}[14]$.

The present paper reports the dry sliding wear behaviour $\mathrm{A}_{356}-\mathrm{TiB}_{2} \mathrm{MMCs}$ synthesised by an semisolid processing technique thixoforming, which is used to manufacture near net shape components.

\section{FABRICATION WORK}

\section{Fabrication Process}

The $\mathrm{A} 356-5 \% \mathrm{TiB}_{2}$ Composite was prepared byin-situ process using $\mathrm{K}_{2} \mathrm{TiF}_{4}$ and $\mathrm{KBF}_{4}$ salts. The synthesis of composite is based on work done in [13]. The composite was prepared by regular stirring the mixture at 10 minutes intervals for 60 minutes in electric resistant furnace then the melt is poured into moulds and allowed to solidify. The semisolid processed composite is made by thixoforming process where the in-situ composite is reheated to $593^{\circ} \mathrm{c}$ and hold for $40 \mathrm{~min}$ to obtain non-dendrite structure then this reheated composite is poured into high pressure die for forming process at semisolid state. Semisolid processed A356 alloy is also prepared by same process.

\section{Material Properties}

The chemical composition of ascast A356 alloy is shown in Tab1e 1

Table 1: Chemical Composition of A356 Alloy

\begin{tabular}{|c|c|c|c|c|c|c|}
\hline Alloying Elements & Si & Fe & Mn & Mg & Ti & Al \\
\hline Percentage (\%) & 7.01 & 0.406 & 0.0430 & 0.760 & 0.0610 & $91.4 \%$ \\
\hline
\end{tabular}

The micro Vickers hardness of Alloy and composite are obtained at 200g load for dwell time of 10s, hardness value are shown in Table 3 which shows there is increase in hardness value between ascast and thixoformed alloy and composite. The reason is due to formation of non-dendrite structure which is absent in alloy and in-situ composite which is shown in Figure 1.The density of the alloy and composite are measured by Archimedes principle the value of densities are shown in Table 2 
Table 2: Hardness and Density of Materials

\begin{tabular}{|c|l|c|c|}
\hline S.no & \multicolumn{1}{|c|}{ Materials } & $\begin{array}{c}\text { Micro Hardness } \\
(\mathbf{V H N})\end{array}$ & $\begin{array}{c}\text { Density } \\
\left(\mathbf{g} / \mathbf{c m}^{\mathbf{3}}\right)\end{array}$ \\
\hline 1 & A356 alloy & 71 & 2.649 \\
\hline 2 & THIXOFORMED A356 alloy & 76.3 & 2.698 \\
\hline 3 & A356-5\%TiB 2 & 81 & 2.848 \\
\hline 5 & THIXOFORMED A356-5\%TiB2 & 103 & 2.845 \\
\hline
\end{tabular}
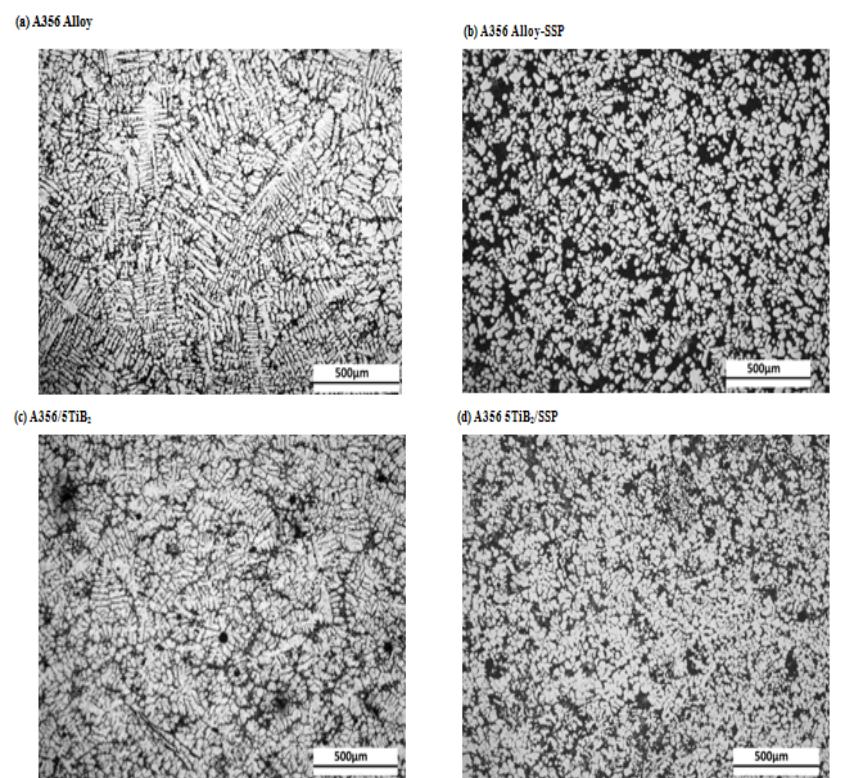

Figure 1: Optical Micro Structure of Alloy (a,b) and Composite(c,d)

There is slight increase in density in range of (0.005-0.050) for thixoformed composite and alloy.

\section{Experimental Details}

Pin on Disc machine is used to characterise the dry sliding wear behavior of the materials. Dry sliding wear test were conducted according to ASTM standard G99-04a.A cylindrical pin of dia $8 \mathrm{~mm}$ and height $25 \mathrm{~mm}$ is prepared for A356 alloy, in-situ $\mathrm{A} 356-5 \% \mathrm{TiB}_{2}$, thixoformed $\mathrm{A} 356$ alloy and thixoformed $\mathrm{A} 356-5 \% \mathrm{TiB}_{2}$ composite for wear test. The disc material is En31 steel (55-60 HRC). Trail experiment was carried out in A356 alloy at sliding velocity 5m/s, sliding load $50 \mathrm{~N}$ and sliding distance 3000m, and it was found that A356 alloy undergo severe adhesive wear called Galling as shown in Figure 2 (a) and Figure 2 (b) at 1000m on further continuation of experiment leads to seizure phenomenon. So, the significant parameters which affect wear property are Load and Sliding Velocity

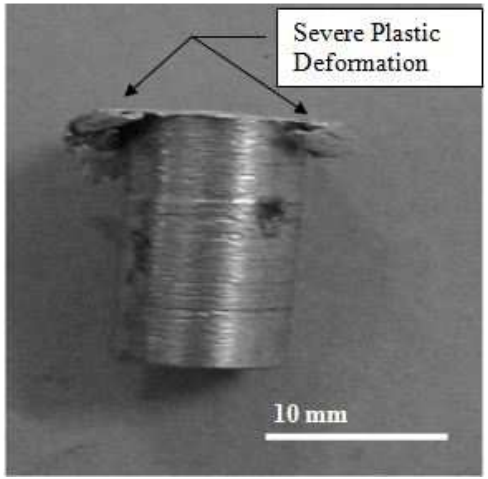

Figure 2(a): Galling in Pin

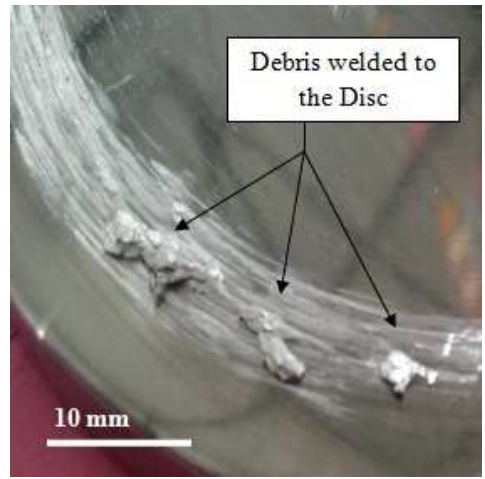

Figure 2 (b): Galling in Disc 
Taguchi L9 orthogonal array is used for characterise the dry sliding wear behaviour of the materials where sliding velocity and load were taken as significant factor which varies from $1 \mathrm{~m} / \mathrm{s}$ to $3 \mathrm{~m} / \mathrm{s}$ and $10 \mathrm{~N}$ to $30 \mathrm{~N}$ respectively, as shown in Table 3.

Table 3: L9 Orthogonal Array

\begin{tabular}{|c|c|c|}
\hline S.no & $\begin{array}{c}\text { Sliding Velocity } \\
(\mathbf{m} / \mathbf{s})\end{array}$ & $\begin{array}{c}\text { Load } \\
(\mathbf{N})\end{array}$ \\
\hline 1 & 1 & 10 \\
\hline 2 & 1 & 20 \\
\hline 3 & 1 & 30 \\
\hline 4 & 2 & 10 \\
\hline 5 & 2 & 20 \\
\hline 6 & 2 & 30 \\
\hline 7 & 3 & 10 \\
\hline 8 & 3 & 20 \\
\hline 9 & 3 & 30 \\
\hline
\end{tabular}

\section{RESULTS}

\section{Wear Test}

The effect of load and sliding velocity on wear rate is shown in Figure 3 which shows that wear rate of in-situ $\mathrm{A} 356-5 \% \mathrm{TiB}_{2}$ is lesser than $\mathrm{A} 356$ alloy and the wear rate of thixoformed A356 alloy and thixoformed composite has greater wear rate than commercial A356 alloy, whereas increase in velocity decrease the wear rate The effect of load on Coefficient of friction is shown in Figure 4(a) which shows that all four materials haveaverage coefficient of friction ranges from ( 3 to 5 ) even on addition of $\mathrm{TiB}_{2}$ particles.

The decrease in wear rate in in-situ composite than alloy is due to presence of secondary phase such as Si and $\mathrm{TiB}_{2}$ as shown in figure 5(a) which restrict the flow of metal during sliding [14].Increase in wear rate in thixoformed A356 alloy is due to breakage of Silicon needles, which tends to increase the ductility of the material which is shown in figure 6(a).Wear rate of all four material shows that increase in load will increase the wear rate but increase in velocity decrease the wear rate, which is due to decrease in contact time between pin and disk to form micro welds on the disc surface, if the velocity is low micro welds will form which restricts the sliding movement of pin at contact surface which leads to removal of material and formation of grooves on pin.[14]

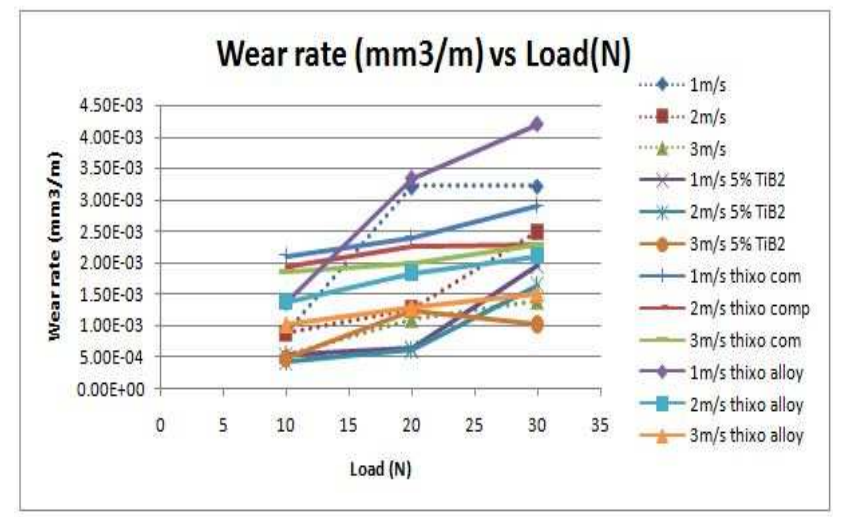

Figure 3: Wear Rate vs. Load 


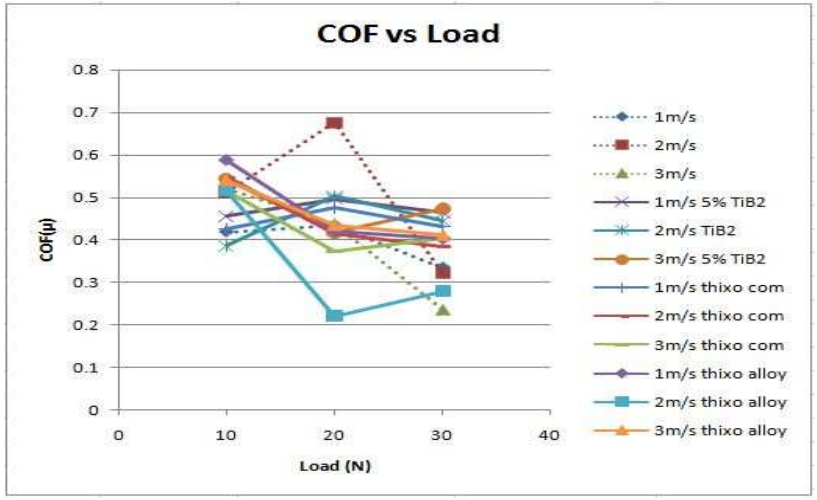

Figure 4 (b): COF vs. Load

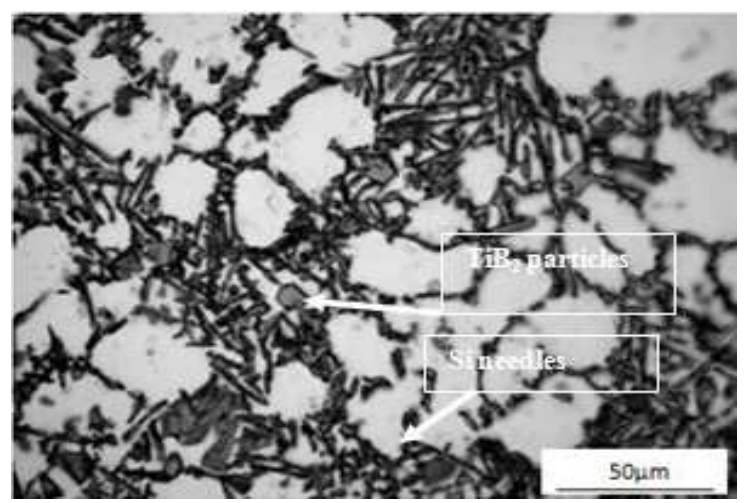

Figure 5 (a): Optical Microstructure of in-situ $\mathrm{A356}^{3} \mathbf{5} \mathrm{TiB}_{2}$

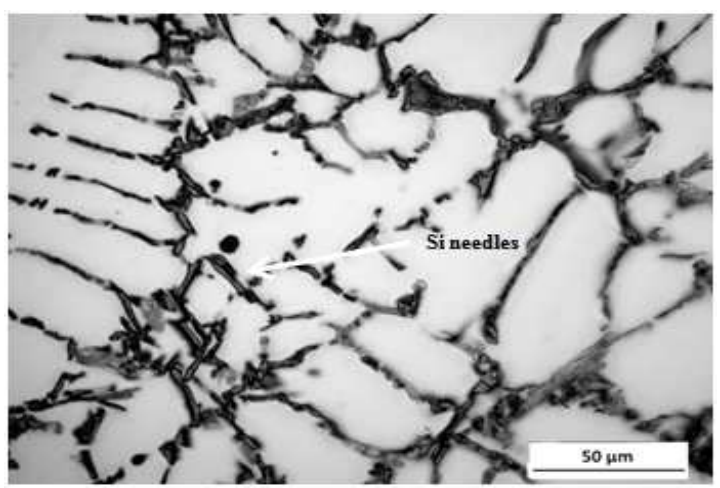

Figure 5 (b): Optical Microstructure of A356 Alloy

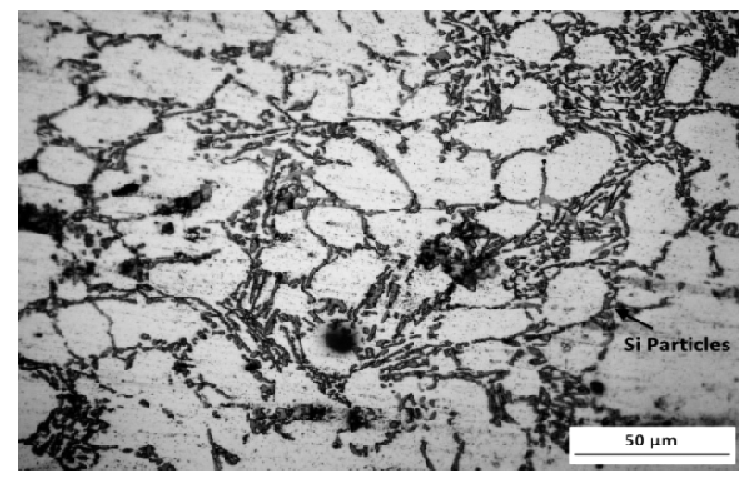

Figure 6 (a): Optical Microstructure of Thixoformed A356 Alloy 


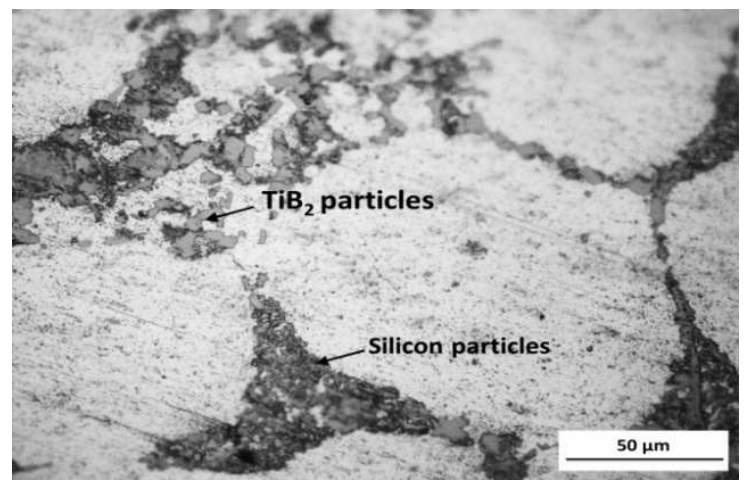

Figure 6 (b): Optical Microstructure of Thixoformed A356-5\% TiB $_{2}$

From Figure 5(a),(b) and Figure 6 (a),(b) we can see that the size of silicon needles get reduced which is smaller in Semisolid processed alloy and composite because of high pressure used in thixoforming.This breakage leads to increase the wear rate.

\section{Mini Tab Results}

Taguchi L9 orthogonal array is used to characterise the wear behavior of the all four materials. The wear rate and COF of four materials is shown in below Table 4

Table 4: Wear Rate and COF of Four Materials

\begin{tabular}{|c|c|c|c|c|c|c|c|c|c|c|}
\hline \multirow[b]{2}{*}{ S.no } & \multirow{2}{*}{$\begin{array}{c}\text { Sliding } \\
\text { Velocity } \\
(\mathrm{m} / \mathrm{s})\end{array}$} & \multirow[b]{2}{*}{$\begin{array}{l}\text { Load } \\
(\mathbf{N})\end{array}$} & \multicolumn{2}{|c|}{ A356 Alloy } & \multicolumn{2}{|c|}{$\mathrm{A}^{356-5 \%} \mathrm{TiB}_{2}$} & \multicolumn{2}{|c|}{$\begin{array}{c}\text { THIXOFORMED } \\
\text { A356 Alloy }\end{array}$} & \multicolumn{2}{|c|}{$\begin{array}{l}\text { THIXOFORME } \\
\text { D A356-5\% } \text { TiB }_{2}\end{array}$} \\
\hline & & & $\begin{array}{c}\text { Wear } \\
\text { Rate } \\
(\mathrm{mm} 3 / \mathrm{m})\end{array}$ & $\begin{array}{c}\mathrm{COF} \\
(\mu)\end{array}$ & $\begin{array}{c}\text { Wear } \\
\text { Rate } \\
(\mathrm{mm} 3 / \mathrm{m})\end{array}$ & $\begin{array}{c}\mathrm{COF} \\
(\boldsymbol{\mu})\end{array}$ & $\begin{array}{c}\text { Wear } \\
\text { Rate } \\
(\mathrm{mm} 3 / \mathrm{m})\end{array}$ & $\begin{array}{l}\mathrm{COF} \\
(\mu)\end{array}$ & $\begin{array}{c}\text { Wear } \\
\text { Rate } \\
(\mathrm{mm} 3 / \mathrm{m})\end{array}$ & $\underset{(\mu)}{\operatorname{COF}}$ \\
\hline 1 & 1 & 10 & & 41950 & & 0.455500 & $1.36 \mathrm{E}-03$ & 0.5870 & $2.11 \mathrm{E}-03$ & 0.4260 \\
\hline 2 & 1 & 20 & $3.21 \mathrm{E}-03$ & & $.32 \mathrm{E}-04$ & & $3.34 \mathrm{E}-03$ & 0.4200 & $2.40 \mathrm{E}-03$ & 0.4760 \\
\hline 3 & 1 & & & & & & $4.20 \mathrm{E}-03$ & & $2.91 \mathrm{E}-03$ & 0.4311 \\
\hline 4 & 2 & 10 & 870504 & & $401 \Gamma$ & 0.386600 & $1.38 \mathrm{E}-03$ & 0.5155 & $1.94 \mathrm{E}-03$ & 0.5470 \\
\hline 5 & 2 & 20 & & & & & $1.84 \mathrm{E}-03$ & 0.2207 & $2.26 \mathrm{E}-03$ & 0.4145 \\
\hline 6 & 2 & 30 & $2.49 \mathrm{E}-03$ & & $1.64 \mathrm{E}-03$ & 0.444000 & $2.10 \mathrm{E}-03$ & 0.2791 & $2.28 \mathrm{E}-03$ & 0.3830 \\
\hline 7 & 3 & 10 & $5.45 \mathrm{E}-04$ & 0.52100 & $4.80 \mathrm{E}-04$ & 0.542500 & $1.01 \mathrm{E}-03$ & 0.5395 & $1.85 \mathrm{E}-03$ & 0.5160 \\
\hline 8 & 3 & 20 & $1.09 \mathrm{E}-03$ & 0.43725 & $1.24 \mathrm{E}-03$ & 0.417368 & $1.27 \mathrm{E}-03$ & 0.4355 & $1.98 \mathrm{E}-03$ & 0.3740 \\
\hline 9 & 3 & 30 & $1.39 \mathrm{E}-03$ & 0.23660 & $1.02 \mathrm{E}-03$ & 0.473500 & $1.50 \mathrm{E}-03$ & 0.4121 & $2.28 \mathrm{E}-03$ & 0.4040 \\
\hline
\end{tabular}

Wear rate and Coefficient of friction of A356 alloy isless at 3m/s and $30 \mathrm{~N}$ as shown in Figure 7. 

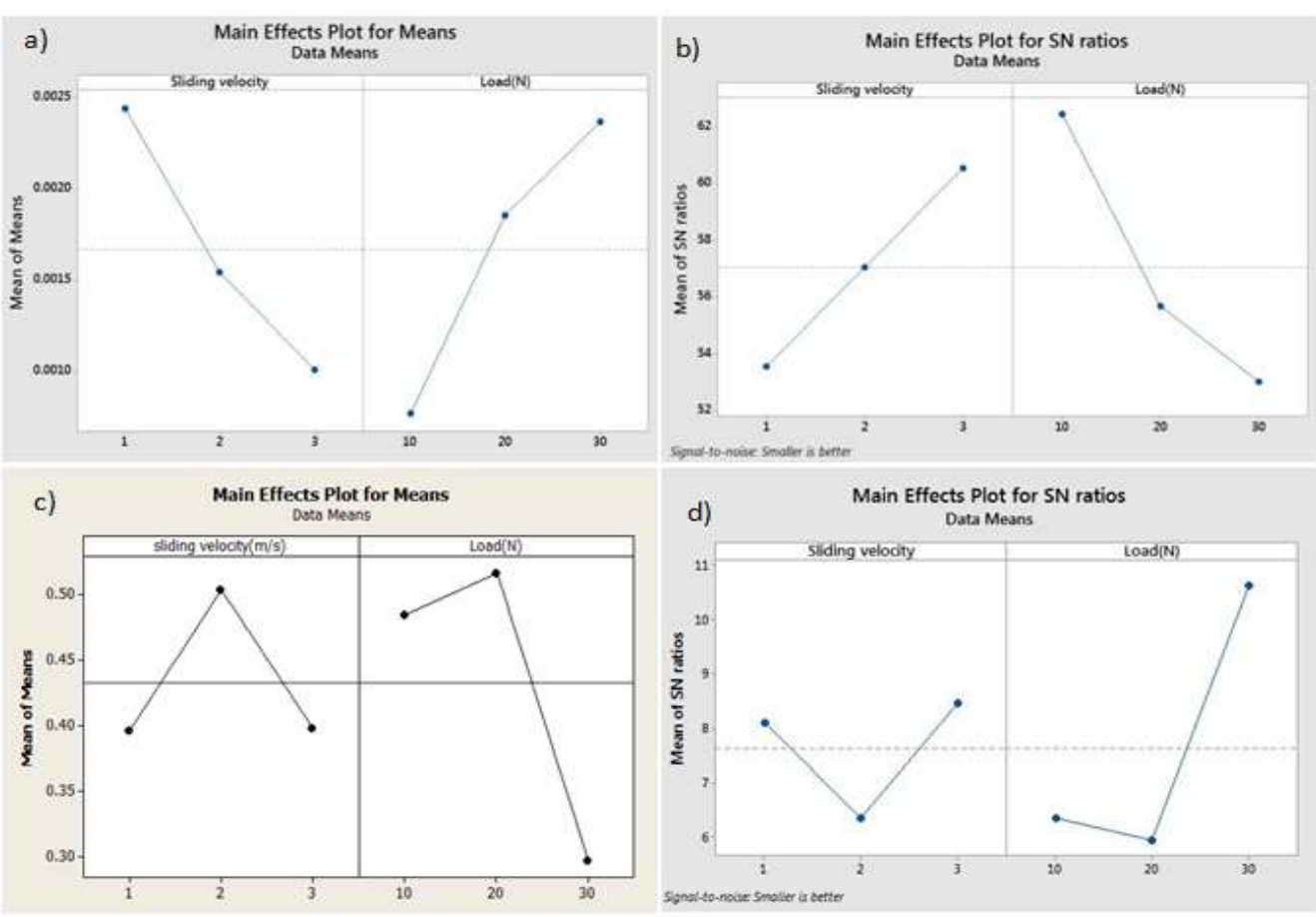

Figure 7: Mean Effects Plot for Mean a) Wear Rate, c) COF, Mean Effect Plots for S/N Ratio b) Wear Rate, d)COF

Wear rate and Coefficient of friction of in-situ $\mathrm{A}_{356}-5 \% \mathrm{TiB}_{2}$ composite is low at $2 \mathrm{~m} / \mathrm{s} 10 \mathrm{~N}$ and $30 \mathrm{~N}$ as shown in Figure 8
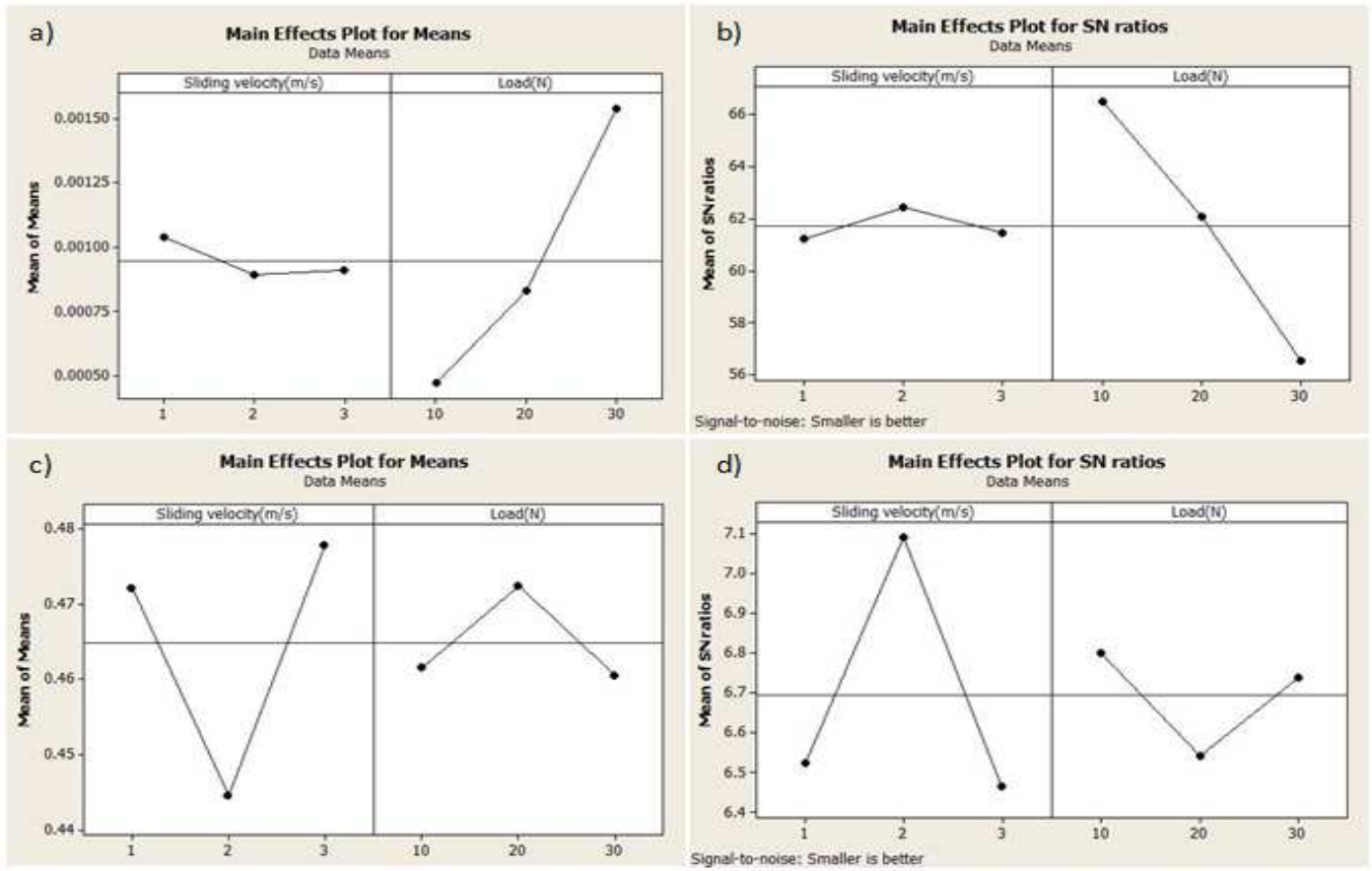

Figure 8: Mean Effect Plot for Mean a) Wear Rate, c) COF Mean Effect Plot for S/N Ratio b) Wear Rate, d) COF

Wear rate and for thixoformed A356 alloy is less at 3m/s $10 \mathrm{~N}$ and Coefficient of friction is minimum at $2 \mathrm{~m} / \mathrm{s}$ and $20 \mathrm{~N}$ as shown in figure 9. 

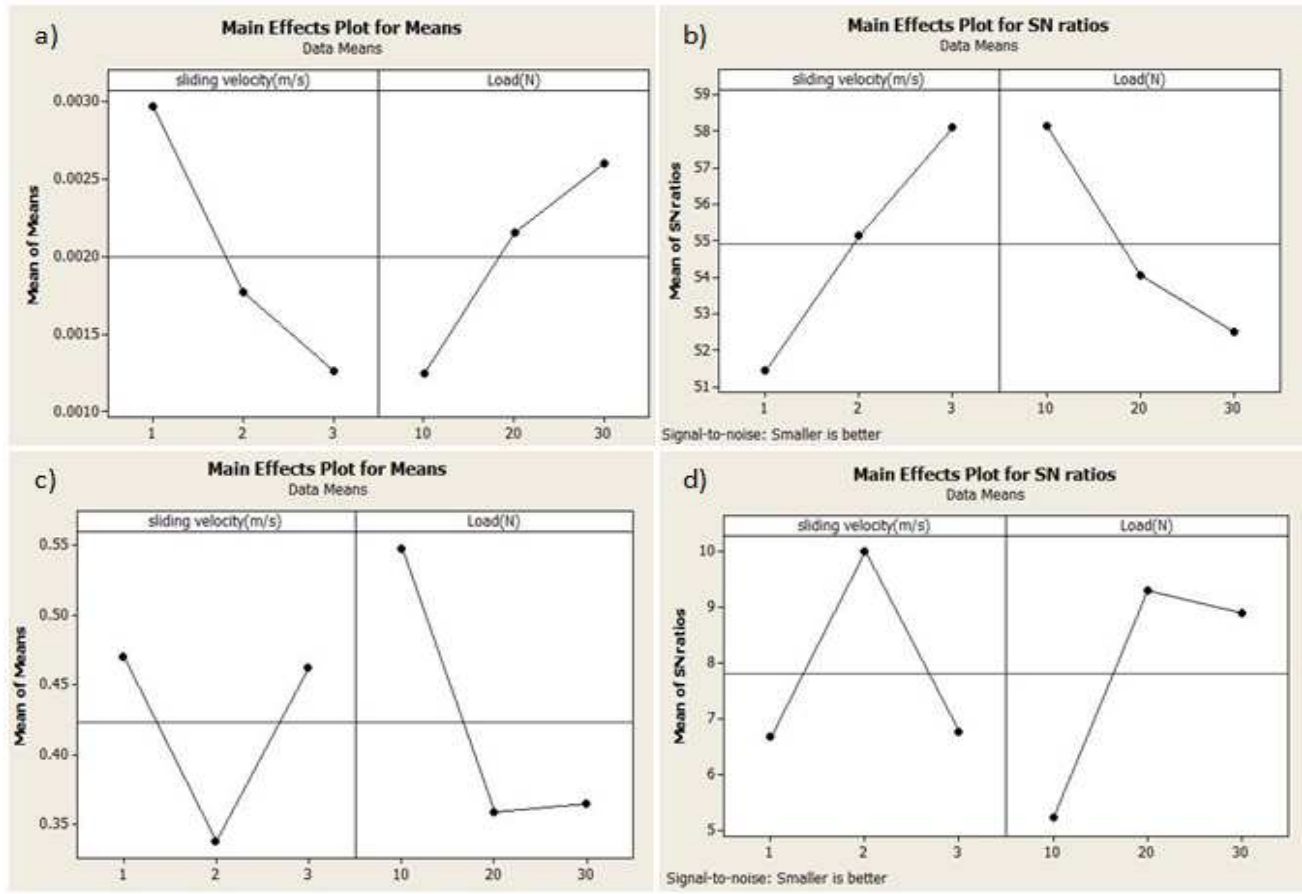

Figure 9: Mean Effect Plot for Mean a) Wear Rate, b) COF, Mean Effect Plot for S/N Ratio c) Wear Rate, d) COF

Wear rate and Coefficient of friction of thixoformed $\mathrm{A} 356-5 \% \mathrm{TiB}_{2}$ is less at $3 \mathrm{~m} / \mathrm{s} 10 \mathrm{~N}$ as shown in Figure 10
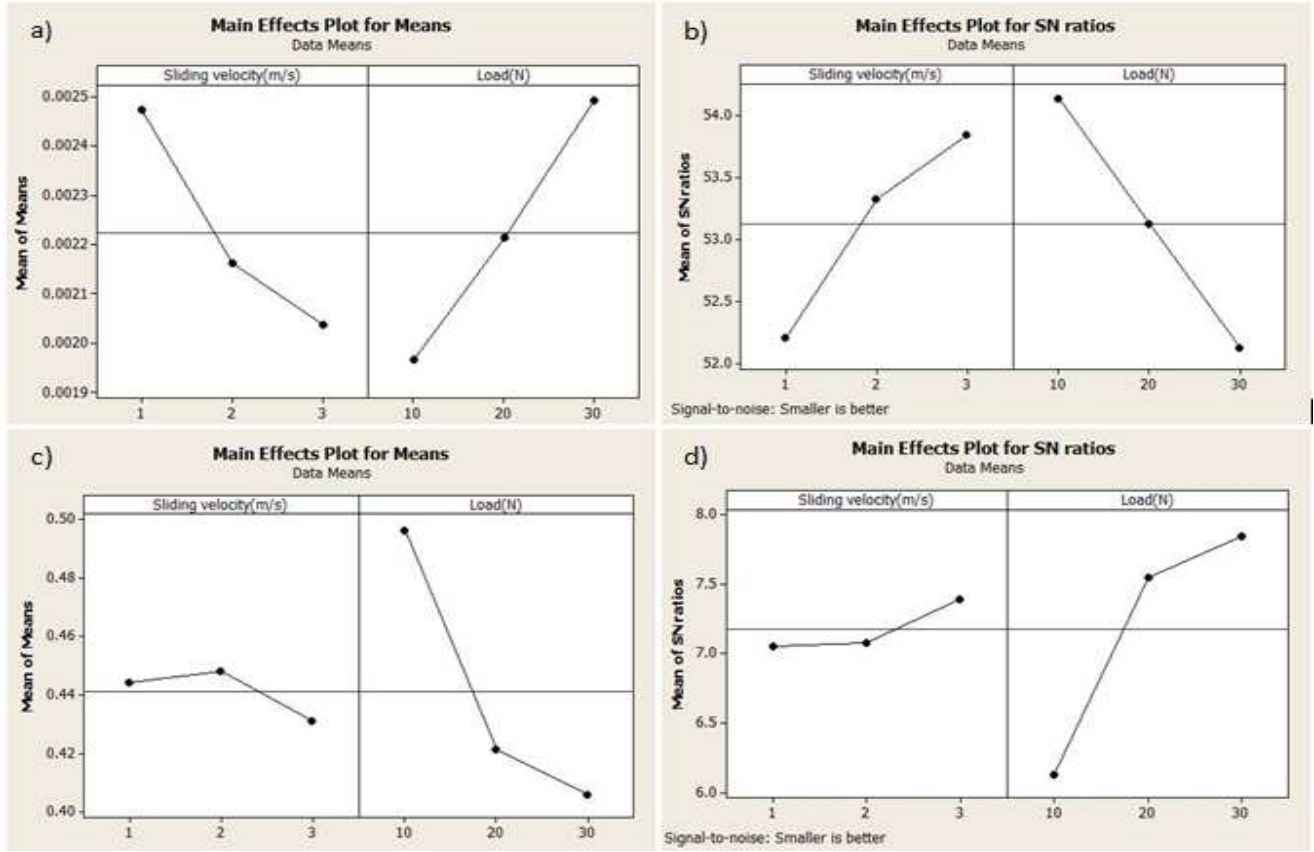

Figure 10: Mean Effect Plot for Mean a) Wear Rate, c) COF, Mean Effect Plot for S/N Ratio b) Wear Rate, d) COF

Thus, from Minitab Mean effect plot of Mean and S/N ratio of Wear rate and Coeffient of friction shows that wear rate is significantly affected by Load and Sliding Velocity. 


\section{CONCLUSIONS}

- Wear rate of in-situ $\mathrm{A}_{356-5 \%} \mathrm{TiB}_{2}$ is less than $\mathrm{A} 356$ alloy

- Wear rate is Maximum at $1 \mathrm{~m} / \mathrm{s} 30 \mathrm{~N}$ and Minimum at $3 \mathrm{~m} / \mathrm{s} 10 \mathrm{~N}$

- Wear rate of thixoformed alloy and thixoformed Composite is greater than commercial alloy and in-situ composite

- Which is due to breakage of silicon needles which increase the ductility of the material

- Wear behavior of thixoformed alloy and thixoformed Composite is yet to interpret.

- Coefficient of friction doesn't change much, which is contradictory result from other research papers that require further interpretation

\section{REFERENCES}

1. K.K.Chawla, Composite Materials: Science and Engineering, 3rd ed. Springer, 2012.

2. T.S.Eyre, "Wear characteristics of Metals", Tribology International, Vol.9, pp.1-10, 1976.

3. S.Suresh, N.Shenbaga Vinayaga Moorthi, “Aluminium-Titanium Diboride(Al-TiB ${ }_{2}$ ) Metal Matrix Composites: Challenges and Opportunities",Procedia Engineering, vol.38, pp.89-97, 2012.

4. R.L.Deuis, C.Subramanian and J.M.Yellup, "Dry sliding wear of Aluminum Composite-A review”,Composite science and Technology,vol.57,pp.415-435,1997

5. H.Torbian, J.P.Pathak and S.N.Tiwari, “Wear characteristics of Al-Si alloys”, Wear,vol.172,pp.49-58, 1993.

6. A.D.Sarkar, “Wear of Aluminium-Silicon Alloys”, Wear, vol.31,pp.331-343,1975.

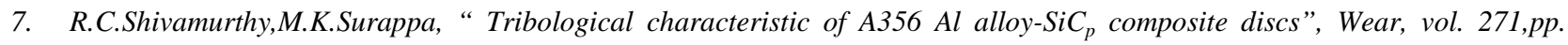
1946-1950,2011

8. K.Mohammed Jasim, E.S.Dwarakadasa., “Wear in Al-Si alloys under dry sliding condition”, Wear,vol.119,pp.119-130,1987.

9. S.A.Kori, T.M.Chandrashekharaiah, “Studies on Dry sliding wear behaviour of hypoeutectic and eutectic Al-Si alloys”, Wear, vol. 263,pp.745-755,2007.

10. Nagaral, M., Auradi, V., \& Ravishankar, M. K. (2013). mechanical behaviour of aluminium 6061 alloy reinforced with al2o3 \& graphite particulate hybrid metal matrix composites. International Journal of Research in Engineering \& Technology (IJRET) Vol, 1, 193-198.

11. S.Suresh,N.Shenbaga Vinayaga Moorthi,S.C.Vettivel and N.Selvakumar, "Mechanical behaviour and wear prediction of stir cast Al-TiB ${ }_{2}$ composite using response surface methodology”, Material and design, vol.59,pp.383-396,2014.

12. S.A.Sajjadi, H.R.Ezatpour and M. Torabi Parizi, "Comparison of microstructure and mechanical properties of A356 aluminum alloy/ $/ \mathrm{A}_{2} \mathrm{O}_{3}$ composite fabricated by stir and compo castig process",Materials and Design, vol.34,pp.106-111,2012.

13. S.Kumar, M.Chakraborty, V.Subramanya Sarma and B.S.Murty, "Tensile and Wear behaviour of in-situ Al-7Si/TiB 2 particulate composite”, Wear, vol.265, pp.134-142, 2008.

14. A.Mandal, B.S.Murty and M.Chakraborty, "Sliding wear behaviour of T6 treated A356-TiB ${ }_{2}$ in-situ composites", Wear, vol.266, pp.865-875, 2009. 
15. LI.yuan-dong.D.Apelian, Xing Bo, MA Ying and HAO Yuan, "Commercial AM60 alloy for semisolid processing: Alloy optimization and thermodynamic analysis”, Trans.NonferrousMet.Soc.China, vol.20, pp.1572-1578.2010.

16. Reddy, A. C. (2015). Studies on loading, cracking and clustering of particulates on the strength and stiffness of 7020/SiCp metal matrix composites. International Journal of Metallurgical \& Materials Science and Engineering, 5(1), 53-66.

17. N. Sivashanmugam, G.Sai Krishnan Performance Analysis Of Stitched And Unstitched Glass Fiber With Jute Material Using Epoxy Laminates international journal for research 